\title{
Influence of electrical conductivity on water uptake and vase life of cut gladiolus stems ${ }^{(1)}$
}

\author{
LUCAS CAVALCANTE DA COSTA(2)*, FERNANDA FERREIRA DE ARAÚJO(3), \\ TERESA DRUMMOND CORREIA MENDES(2) e FERNANDO LUIZ FINGER(2)
}

\begin{abstract}
Several experiments reveal that distilled water varies among different laboratories and also does not have a standard composition. Water electrical conductivity (EC) of vase solution is one of the parameters that influence the water uptake by cut flowers. Therefore, the objective of this work was to evaluate the influence of electrical conductivity on water uptake and vase life in cut stems of gladiolus. The stems harvested and kept in distilled water $\left(\mathrm{pH} 6.6, \mathrm{EC}<0.01 \mathrm{dS} \mathrm{m}^{-1}\right)$ and tap water $\left(\mathrm{pH} 7.0, \mathrm{EC} 0.75 \mathrm{dS} \mathrm{m}^{-1}\right)$ at room temperature. Flowers kept in tap water showed lower fresh weight loss after the second day and higher water uptake during vase life. In a second set of experiments, we verified the limit EC saturation supported by the flower. For this, flowers were placed in individual test tubes containing four different solutions with varying ion concentrations. Solution 2 (EC $0.60 \mathrm{dS} \mathrm{m}^{-1}$ ) promoted increased vase life and allowed maximum water uptake by the flowers. The results show that the electrical conductivity of vase solution is a major parameter in experiments with vase life of cut gladiolus. The presence of ions in the vase solution increases the overall vase life and improves water uptake of flowers with favorable optimal EC between 0.60 to $0.87 \mathrm{dS} \mathrm{m}^{-1}$.
\end{abstract}

Keywords: Gladiolus grandiflora Hort., cut flowers, distilled water, longevity,

\section{RESUMO}

Influência da condutividade elétrica na absorção de água e vida de vaso de flores de gladíolos

Diversos experimentos revelam que a qualidade da água destilada varia entre os diferentes laboratórios. A condutividade elétrica (CE) da solução de vaso é um dos parâmetros que influenciam na absorção de água pelas flores de corte. Portanto, o objetivo deste trabalho foi avaliar a influência da condutividade elétrica na absorção de água e vida de vaso de hastes de gladíolos. As hastes foram colhidas e mantidas em água destilada ( $\mathrm{pH} 6,6 ; \mathrm{CE}<0.01 \mathrm{dS} \mathrm{m}^{-1}$ ) e água da torneira $(\mathrm{pH} 7,0 ; \mathrm{CE}$ $0,75 \mathrm{dS} \mathrm{m}^{-1}$ ), sob condições de temperatura ambiente. As flores mantidas em água de torneira apresentaram menor perda de peso fresco após segundo dia e maior absorção de água durante a vida de vaso. Em segundo experimento, verificou-se o limite de saturação da CE suportada pela flor. Para isso, as flores foram colocadas em tubos de ensaio individuais contendo quatro diferentes soluções com distintas concentrações de íons. Solução 2 (CE $\left.0,60 \mathrm{dS} \mathrm{m}^{-1}\right)$ promoveu o aumento da vida de vaso e o consumo máximo de água pelas flores. Os resultados mostram que a condutividade elétrica da solução de vaso é um parâmetro importante a ser avaliado em experimentos com a pós-colheita de flores de gladíolos. A presença de íons na solução de vaso aumenta a longevidade e melhora a absorção de água das hastes, com CE favorável entre 0,60-0,87 dS m ${ }^{-1}$.

Palavras-chave: Gladiolus grandiflora Hort., flores de corte, água destilada, longevidade,

\section{INTRODUCTION}

Cut flower spoilage is the result of tissue senescence, microbial growth, and excessive water loss (AHMAD et al., 2011). Water balance involves physiological processes including the absorption capacity, ability to transport water and finally losses through transpiration (FINGER et al., 2006). The quality of the water in which the cut flowers are stored is an important factor that influences longevity. Water is the medium for the solutes diffusion, maintenance of plant tissue turgor, solvent for most biochemical reactions and helps on tissue temperature control (VAN MEETEREN et al., 2001; AHMAD et al., 2013). According to Saleem et al. (2014), any tap water should be analyzed before using in cut flower handling and, if possible, be specific for each variety (AHMAD et al., 2013).

Previous study indicated that there is still no general accepted standard water as control vase solution used in experiments on postharvest cut flowers. Tap water composition varies among different regions or even within a single location. Also, distilled water may change among different laboratories making difficult comparisons between different experiments (VAN MEETEREN, 2000).The electrical conductivity of the water is one of the parameters evaluated to determine the physical characteristic and can influence the uptake by cut flowers (REGAN and DOLE, 2010). Therefore, the objective of this work was to evaluate the influence of electrical conductivity on water uptake and vase life in cut stems of gladiolus.

\footnotetext{
(1) Received in 11/10/2014 and approved in 20/05/2015

(2) Universidade Federal de Viçosa (UFV), Departamento de Fitotecnia, Viçosa-MG, Brazil. *Corresponding author: costalc@ymail.com

(3) Universidade Federal de Viçosa (UFV), Departamento de Biologia Vegetal, Viçosa-MG, Brazil.
} 


\section{MATERIAL AND METHODS}

Flower stalks of gladiolus (Gladiolus grandiflora Hort.) cv. Gold Field were purchased from a commercial production facility located in the rural area of ViçosaMG, Brazil (latitude $20.45^{\circ} \mathrm{S}$, longitude $42.51^{\circ} \mathrm{W}, 651 \mathrm{~m}$ a.s.1.). Each stem contained only one fully open flower (commercial harvest). The stems were selected and standardized to $60 \mathrm{~cm}$ long. The base cut section was kept under water to prevent embolisms. The experiments were conducted at $25 \pm 5^{\circ} \mathrm{C}$, relative humidity $60 \pm 20 \%$ and under white light (intensity of $10 \mathrm{mmol} \mathrm{m}^{-2} \mathrm{~s}^{-1}$ ).

In the first experiment, cut stems were placed in individual test tubes containing $100 \mathrm{~mL}$ of distilled water (pH $6.65, \mathrm{EC}<0.01 \mathrm{dS} \mathrm{m}^{-1}$ ) or in $100 \mathrm{~mL}$ of the tap water ( $\mathrm{pH} 7.07, \mathrm{EC} 0.75 \mathrm{dS} \mathrm{m}^{-1}$ ). The composition of tap water was released by company supplier (Table 1).

Table 1. Composition of local tap water Tabela 1. Composição da água de torneira local

\begin{tabular}{|c|c|}
\hline Compounds & Concentration $\left(\mathbf{m g ~ L}^{-1}\right)$ \\
\hline Chloride $\left(\mathrm{Cl}^{-}\right)$ & 4.4 \\
\hline Carbonate $\left(\mathrm{CO}_{3}^{2-}\right)$ & 0.02 \\
\hline Sulphate $\left(\mathrm{SO}_{4}^{2-}\right)$ & 1.22 \\
\hline Nitrate $\left(\mathrm{NO}_{3}^{-}\right)$ & 0.64 \\
\hline Nitrite $\left(\mathrm{NO}_{2}^{-}\right)$ & 0.04 \\
\hline Ammonium $\left(\mathrm{NH}_{4}^{+}\right)$ & 0.02 \\
\hline Phosphate $\left(\mathrm{PO}_{4}^{3-}\right)$ & 0.07 \\
\hline Iron $(\mathrm{Fe})$ & 0.07 \\
\hline Aluminum $(\mathrm{Al})$ & $<0.10$ \\
\hline Lead $(\mathrm{Pb})$ & $<0.01$ \\
\hline Cadmium $(\mathrm{Cd})$ & 0.05 \\
\hline Zinc $(\mathrm{Zn})$ & 0.34 \\
\hline
\end{tabular}

Daily were determined vase life (end of vase life defined as the day that $30 \%$ of open flowers met wilted), fresh weight loss and rate of water absorption (DOORN et al., 2002; SANTOS et al., 2012).

In the second experiment the flowers were placed in individual test tubes containing $100 \mathrm{~mL}$ of the distilled water with 4 different solutions with varying ion concentrations: $125 \mathrm{mg} \mathrm{L}^{-1} \mathrm{NaHCO}_{3}, 99 \mathrm{mg} \mathrm{L}^{-1} \mathrm{CaCl}_{2}$, $1.2 \mathrm{mg} \mathrm{L}^{-1} \mathrm{CuSO}_{4}$ (Solution 1: EC $0.31 \mathrm{dS} \mathrm{m}^{-1}$ ); 250 $\mathrm{mg} \mathrm{L}^{-1} \mathrm{NaHCO}_{3}, 198 \mathrm{mg} \mathrm{L}^{-1} \mathrm{CaCl}_{2}, 2.4 \mathrm{mg} \mathrm{L}^{-1} \mathrm{CuSO}_{4}$ (Solution 2: EC $0.60 \mathrm{dS} \mathrm{m}^{-1}$ ); $375 \mathrm{mg} \mathrm{L}^{-1} \mathrm{NaHCO}_{3}, 297$ $\mathrm{mg} \mathrm{L}^{-1} \mathrm{CaCl}_{2}, 3.6 \mathrm{mg} \mathrm{L}^{-1} \mathrm{CuSO}_{4}$ (Solution 3: EC 0.87 $\mathrm{dS} \mathrm{m}{ }^{-1}$ ) and $500 \mathrm{mg} \mathrm{L}^{-1} \mathrm{NaHCO}_{3} 396 \mathrm{mg} \mathrm{L}^{-1} \mathrm{CaCl}_{2}$, $4.8 \mathrm{mg} \mathrm{L}^{-1} \mathrm{CuSO}_{4}$ (Solution 4: EC $1.34 \mathrm{dS} \mathrm{m}^{-1}$ ) adapted from Van Meeteren et al. (2000). The flower stalks were evaluated daily for vase life, accumulated weight loss and accumulated water absorption. The experiment was conducted in a completely randomized design with three stems for each experimental unit, with four replicates each. Data were subjected to statistical analysis of variance (ANOVA), regression and descriptive statistics in percentage based on the average values and standard error of the mean. We adopted the Tukey test at $P<0.01$. The choice of the regression model based on the significance of the regression models using the test $t$ at $P<0.05$ and biological behavior under study.

\section{RESULTS AND DISCUSSION}

Stalks of Gladiolus grandiflora kept in tap water had better development of flower and improved retention of water up the $4^{\text {th }}$ day compared to those kept in distilled water (Figure 1). In addition, the vase life of flowers was significantly increased by tap water compared with distilled water (Figure 2).

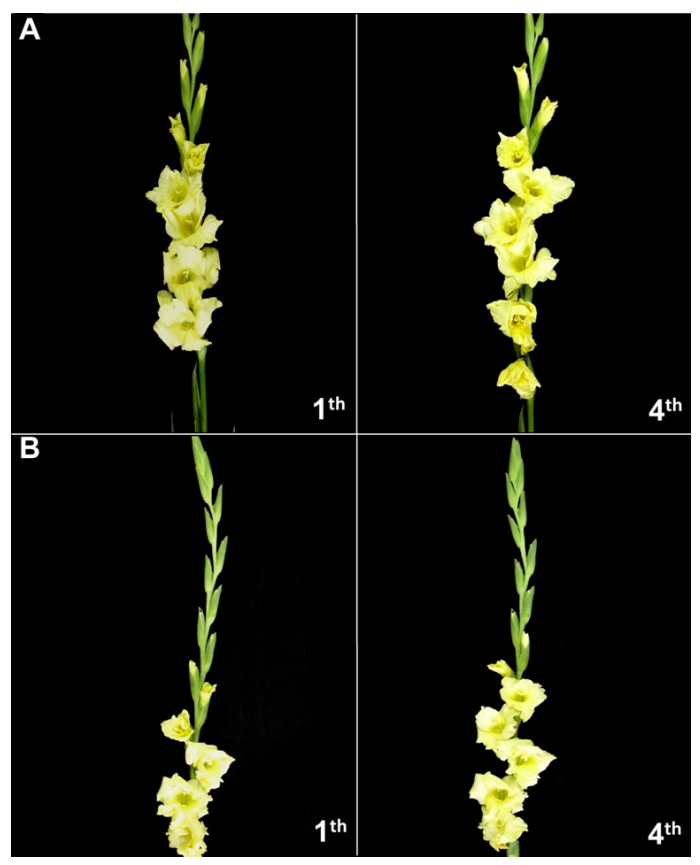

Figure 1. Appearance of gladiolus flowers in distilled water (A) and tap water (B), after 1 or 4 days of storage at $20^{\circ} \mathrm{C}$. Figura 1. Aparência de flores de gladiolos mantidas em água destilada (A) e água de torneira (B), após o $1^{\circ}$ ou $4^{\circ}$ dia de acondicionamento a $20^{\circ} \mathrm{C}$. 


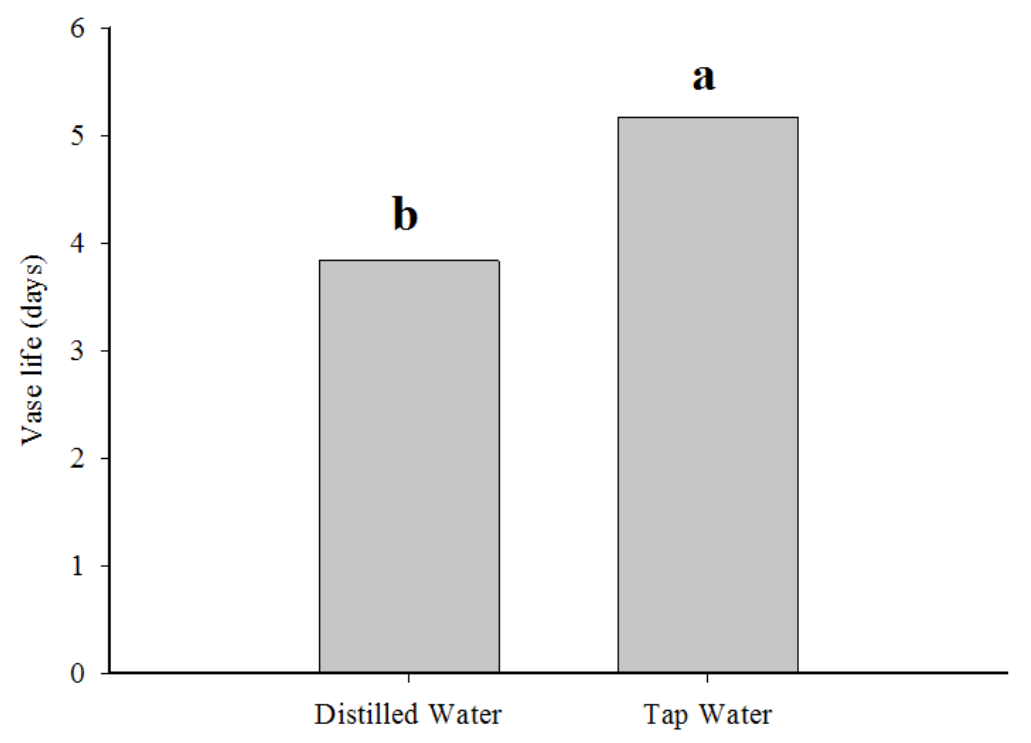

Figure 2. Vase life of gladiolus stems kept in distilled and tap water.

Different letters indicate significant differences based on a Tukey test at $\mathrm{P}<0.01$

Figura 2. Vida de vaso de hastes de gladiolos mantidas em água destilada e água de torneira. Letras diferentes indicam diferença significativa pelo teste de Tukey $(P<0,01)$.

Regardless if the stems were kept in distilled or tap water, there was a linear decrease in the fresh weight beginning first after harvest. Flower in the tap water had $-6.1 \%$ day $^{-1}$ rate of decrease on the fresh weight, while in distilled water the daily rate was $-8.5 \%$ (Figure 3 ).

Stalks kept in tap water showed the lowest weight loss after second day and increased water uptake throughout vase life when compared to distilled water (Figures 3 and 4). Water uptake showed a fast increase in the first day up to $500 \mathrm{mg} \mathrm{g}^{-1} \mathrm{FW}$, keeping the same rate up to the second day, followed by a decreased capacity of absorption regardless if they were kept in tap or distilled water. The lowest capacity of water uptake occurred between the third and fourth day (Figure 4).

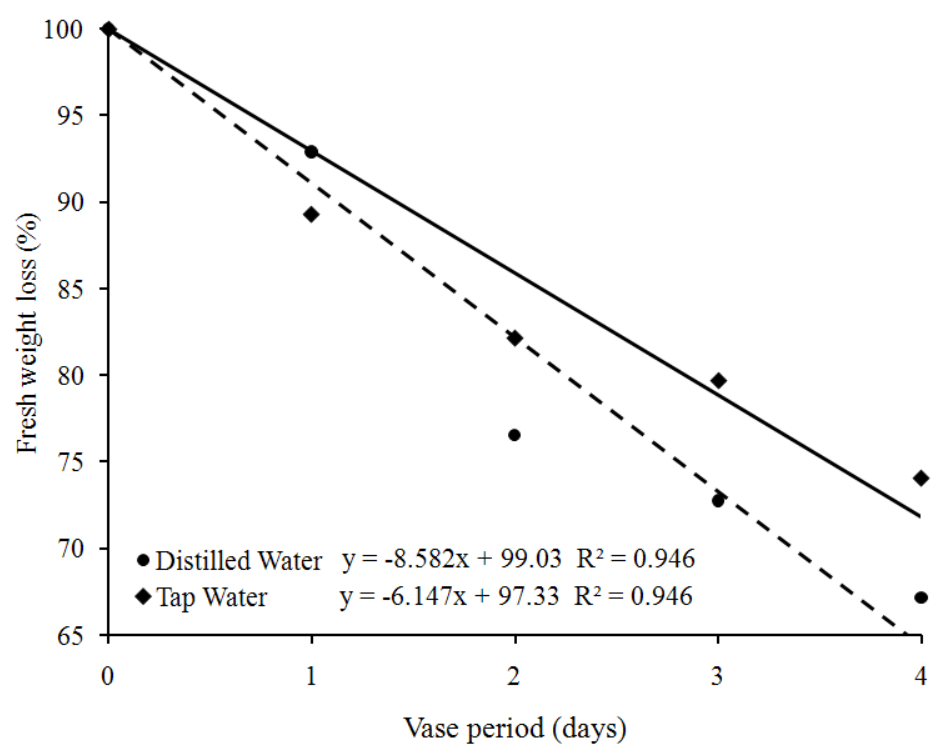

Figure 3. Fresh weight loss of gladiolus stems kept in distilled water $\left(-8.5 \%\right.$ day $\left.^{-1}\right)$ and tap water $\left(-6.1 \%\right.$ day $\left.^{-1}\right)$ during vase life.

Figura 3. Perda de peso fresco de hastes de gladiolos mantidas em água destilada $\left(-8,5 \%\right.$ dia $\left.{ }^{-1}\right)$ e água de torneira $\left(-6,1 \%\right.$ dia $\left.^{-1}\right)$ durante a vida de vaso. 


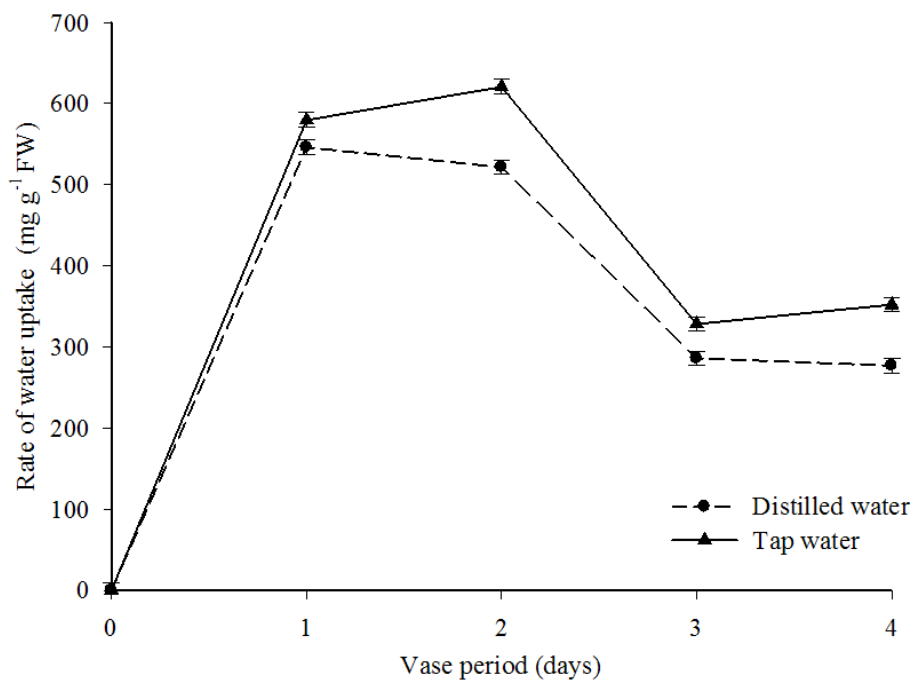

Figure 4. Rate of water uptake of gladiolus stems kept in distilled and tap water during vase life. Vertical bars represent the standard errors of the means.

Figura 4. Taxa de absorção de água em hastes de gladiolos mantidas em água destilada e água de torneira durante a vida vaso. As barras verticais representam o erro-padrão da média.

These results can be explained by the difference in the EC between the vase solutions. Gladiolus is a species that requires a high water uptake in order to maintain equilibrated water status, favoring the opening of flower buds; it appears that the lack of ions in the water inhibits floret opening due to lower absorption of water (BAI et al., 2009).

It is known that excessive salt can also cause damage to the flowers (VALDEZ-AGUILAR et al., 2009). According to Regan and Dole (2010), tap water has many other elements such as $\mathrm{Cu}, \mathrm{Fe}, \mathrm{K}, \mathrm{Mg}, \mathrm{Mn}, \mathrm{P}$ and $\mathrm{Zn}$, which may adversely affect the vase life and were not included in the water. The presence of several different ions may have other physiological effects in addition the increase in EC.
Saleem et al. (2014) showed that carbonated water proved to be the best water to deal with cutting gladiolus, because not only extended longevity, but also kept fresh weight relative, and continued absorption of water by cutting stems. However, in their study used the tap water contained higher heavy metals and salt levels $\left(>3.30 \mathrm{dS} \mathrm{m}^{-1}\right)$.

Stems kept in solution $2\left(198 \mathrm{mg} \mathrm{L}^{-1} \mathrm{CaCl}_{2}, 2.4 \mathrm{mg}\right.$ $\mathrm{L}^{-1} \mathrm{CuSO}_{4}$, EC $0.60 \mathrm{dS} \mathrm{m}^{-1}$ ) showed significantly higher vase life than the other solutions (Figure 5). In addition, showed smaller accumulated fresh weight loss and the highest water uptake during the vase life (Figures 6 and 7). Thus solution 2 was effective in maintaining the flow of water by keeping the hydraulic properties of the xylem vessels.

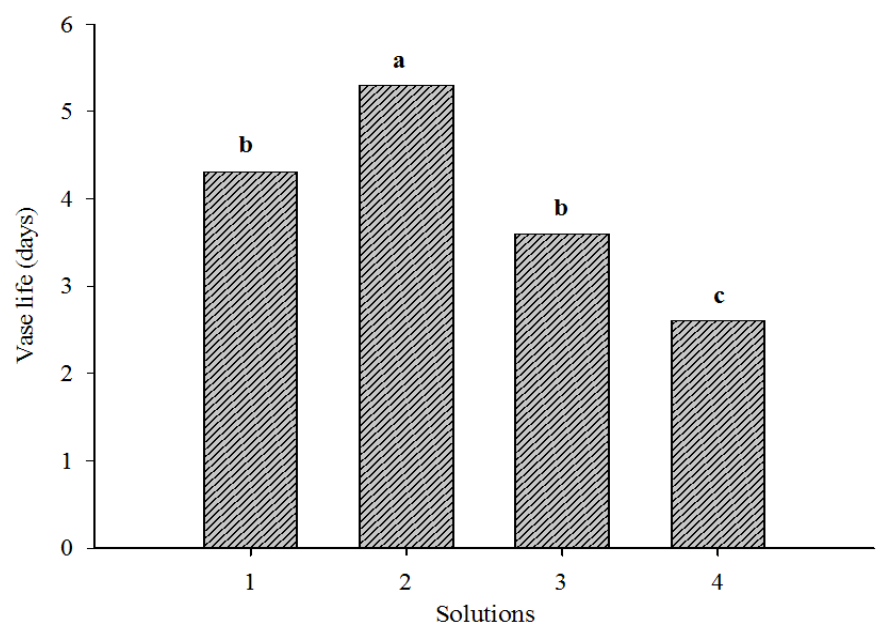

Figure 5. Vase life of gladiolus stems stored at $20^{\circ} \mathrm{C}$ in vase solutions with different ions concentrations.

Different letters indicate significant differences based on a Tukey test at $\mathrm{P}<0.01$.

Figura 5. Vida de vaso de hastes de gladiolos mantidas a $20^{\circ} \mathrm{C}$ em soluções de vaso com diferentes concentrações de ions. Letras diferentes indicam diferença significativa pelo teste de Tukey $(P<0,01)$. 


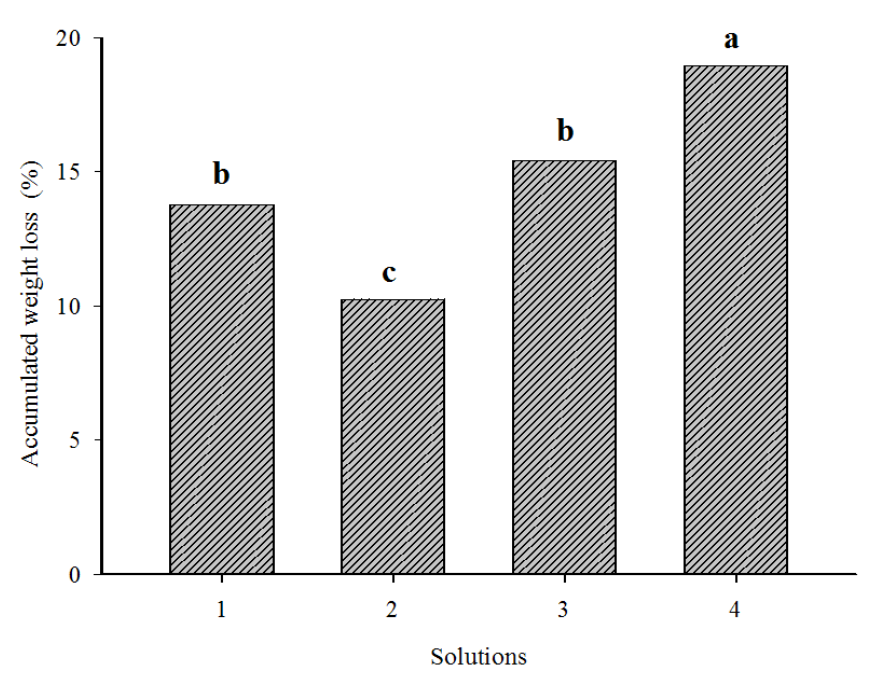

Figure 6. Accumulated weight loss of gladiolus stems stored at $20^{\circ} \mathrm{C}$ in vase solutions with different ions concentrations. Different letters indicate significant differences based on a Tukey test at $\mathrm{P}<0.01$.

Figura 6. Perda acumulada de peso fresco de hastes de gladiolos mantidas a $20^{\circ} \mathrm{C}$ em soluções de vaso com diferentes concentrações de íns. Letras diferentes indicam diferença significativa pelo teste de Tukey $(P<0,01)$

According to Gast (2000), vase life of gladiolus begins to decrease at $1.00 \mathrm{dS} \mathrm{m}^{-1}$. Regan (2008) found an EC of $1.00-1.30 \mathrm{dS} \mathrm{m}^{-1}$ resulted in the longest vase life for three rose cultivars. Ahmad et al, (2013) found that increased EC increased vase life hydrangea, ranging from a short life of 7.3 days to 15.4 of a long $2.5 \mathrm{dS} \mathrm{m}^{-1}$.

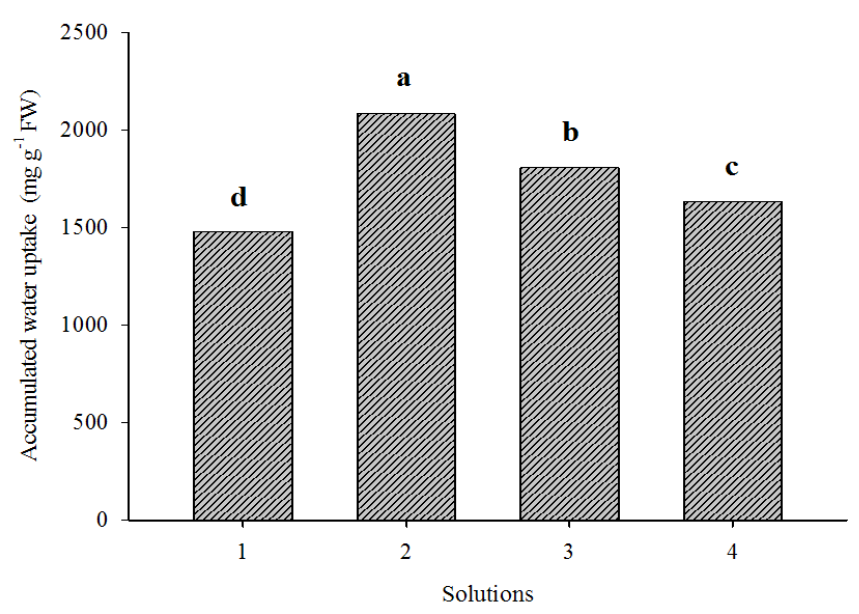

Figure 7. Accumulated water uptake of gladiolus stems stored at $20^{\circ} \mathrm{C}$ in vase solutions with different ions concentrations. Different letters indicate significant differences based on a Tukey test at $\mathrm{P}<0.01$.

Figura 7. Absorção acumulada de água em hastes de gladiolos mantidas a $20^{\circ} \mathrm{C}$ em soluções de vaso com diferentes concentrações de ions. Letras diferentes indicam diferença significativa pelo teste de Tukey $(P<0,01)$

\section{CONCLUSIONS}

The results show that the electrical conductivity of vase solution is a major parameter in experiments with vase life of cut gladiolus. The presence of ions in the vase solution increases the overall vase life and improves water uptake of flowers with favorable optimal electrical conductivity between 0.60 to $0.87 \mathrm{dS} \mathrm{m}^{-1}$.

\section{ACKNOWLEDGMENTS}

To Fundação de Pesquisa do Estado de Minas Gerais (FAPEMIG) and Conselho Nacional de Desenvolvimento Científico e Tecnológico (CNPq) for financial support. 


\section{REFERENCES}

AHMAD, I.; JOYCE, D.C.; FARAGHER, J.D. Physical stem-end treatment effects on cut rose and acacia vase life and water relations. Postharvest Biology and Technology. v.59, p. 258-264, 2011. DOI: <http://dx.doi.org/10.1016/j. postharvbio.2010.11.001>

AHMAD, I.; DOLE, J.M.; CARLSON, A.S; BLAZICH, F.A. Water quality effects on postharvest performance of cut calla, hydrangea, and snapdragon. Scientiae Horticulturae,v.153, p.26-33. 2013. DOI: <http://dx.doi. org/10.1016/j.scienta.2013.01.015>

BAI, J.G.; XU, P.L.; ZONG, C.S.; WANG, C.Y. Effects of exogenous calcium on some postharvest characteristics of cut gladiolus. Agricultural Sciences in China, v.8, p.293-303, 2009. DOI: <http://dx.doi.org/10.1016/S16712927(08)60212-6>

FINGER F.L.; SANTOS V.R.; BARBOSA J.G.; BARROS R.S. Influência da temperatura na respiração, produção de etileno e longevidade de inflorescências de esporinha. Bragantia, v.65, p.363-368, 2006. DOI: <http://dx.doi. org/10.1590/S0006-87052006000300001>

GAST, K.L.B. Water quality for florists - why is it so important. Kansas State Univ. Coop. Ext. Serv. Publ. MF2436, 2000.

REGAN, E.M. Developing water quality and storage standards for cut Rosa stems and postharvest handling protocols for specialty cut flowers. 2008. MS Thesis, NC State University, Raleigh.

REGAN, E.M.; DOLE, J.M. Postharvest handling procedures of Matthiola incana'Vivas Blue'. Postharvest Biology and Technology. v.58, p.268-273, 2010. DOI: $<$ http://dx.doi.org/10.1016/j.postharvbio.2010.07.011>
SANTOS, J.S.; FINGER, F.L.; VIEIRA, L.M.; MENDES, T.D.C.; BARBOSA, J.G. Capacidade de reidratação e influência do corte no restabelecimento do fluxo de água em inflorescências de Epidendrum ibaguense. Revista Brasileira de Horticultura Ornamental, v.18, n.1, p.15-21, 2012. DOI: <http://dx.doi.org/10.14295/rbho. v18i1.689>

SALEEM, M.; KHAN, M.A.; AHMAD, I; AHMAD, R. Vase water effects on postharvest longevity and water relations of Gladiolus grandiflorus 'White Prosperity'. Pakistan Journal of Agricultural Sciences, v.51, n.1, p.137-141, 2014.

VALDEZ-AGUILAR, L.A., GRIEVE, C.M., POSS, J. Hypersensitivity of Ranunculus asiaticus to salinity and alkaline $\mathrm{pH}$ in irrigation water in sand cultures. HortScience, v.44, p.138-144, 2009.

VAN DOORN, W.G.; ABADIE, P.; BELDE, P.J.M. Alkylethoxylate surfactants for rehydration of roses and Bouvardia flowers. Postharvest Biology and Technology, v.24, p. 327-333, 2002. DOI: <http://dx.doi.org/10.1016/ S0925-5214(01)00152-1>

VAN MEETEREN, U.; VAN GELDER, H.;VAN IEPEREN, W. Reconsideration of the use of deionized water as vase water in postharvest experiments on cut flowers. Postharvest Biology and Technology, v.18, p.169-181, 2000. DOI: <http://dx.doi.org/10.1016/S09255214(99)00050-2>

VAN MEETEREN, U.; VAN GELDER, A.; VAN IEPEREN. Should we reconsider the use of deionized water as control vase solutions? Acta Horticulturae, v.543, p.257-264, 2001. 